\title{
The WTO Trade Facilitation Agreement: Implications for Pakistan's Domestic Trade Policy Formulation
}

\section{Mohammad Saeed*}

\begin{abstract}
Recognizing that trade facilitation has contributed significantly to reducing costs and time in cross-border trade, World Trade Organization (WTO) members adopted the new Trade Facilitation Agreement (TFA) at the last ministerial conference in Bali. WTO members are now gearing up to implement the commitments ensuing from the TFA in accordance with the special and differential treatment stipulated for developing countries. This paper assesses the impact of the TFA on Pakistan's national trade policy and shows how the process of policy formulation in Pakistan should be adjusted so that the agreement can be promptly and correctly implemented on a sustainable basis.
\end{abstract}

Keywords: Pakistan, world trade organization, trade facilitation agreement (TFA).

JEL classification: F13, F40.

\section{Introduction}

This paper begins with a brief introduction to the concept of trade facilitation and summarizes the commitments arising from the Trade Facilitation Agreement (TFA) for members of the World Trade Organization (WTO). It then highlights how the TFA is perceived in the context of cost reduction and as a tool for development. The next part examines the current situation of Pakistan vis-à-vis the TFA and offers a snapshot of different international trade facilitation indicators (TFIs) that are published periodically by the World Bank and World Economic Forum. Finally, the paper focuses on the implications for domestic trade policymaking in Pakistan as it prepares to categorize and implement the binding provisions of the TFA.

\footnotetext{
* Senior Technical Adviser on Trade and Transport Facilitation, United Nations Conference on Trade and Development (UNCTAD), Geneva. This paper represents the author's personal opinion and is not meant to represent the position or opinions of UNCTAD or the official position of the author as a staff member.
} 
Trade facilitation is the concept of reducing the costs and time involved in processing cross-border trade transactions. There is no standard definition of trade facilitation but it is universally accepted that it is a way to improve the efficiency of international trade. Institutions ${ }^{1}$ working in this area have evolved their own definitions consistent with their mandate, objectives, and work program. Even a cursory examination of these definitions, however, will show that trade facilitation covers the simplification, harmonization, standardization, and modernization of international trade and customs procedures.

In the context of the trade supply chain, the broader concept of trade facilitation covers every step of the movement of goods from the producer's premises up to the retailer's shelf, whereas the narrow version is confined to the procedures of border regulatory agencies. Quoting Robert Zoellick, ${ }^{2}$ "trade facilitation measures are basically an extension of market access procedures that lower transaction costs and increase timeliness of transit" (cited in International Trade Centre, 2013, p. 1). Simply put, trade facilitation refers to those measures that improve efficiency and transparency in the trade supply chain.

The term may be relatively new, but the concept is not. The three articles of the General Agreement on Tariffs and Trade (GATT) 1994 (Articles V, VIII, and X), which form the basis of the new TFA, have been part of GATT since its beginning in 1947. The World Customs Organization (WCO) has been working in this area for over half a century. The Kyoto Convention and Revised Kyoto Convention cover many of the areas now included in the new TFA. The mandate of the United Nations Conference on Trade and Development (UNCTAD) in this area dates back to the Final Act of its very first ministerial conference in $1964 .^{3}$

Similarly, UNCTAD's Special Program on Trade Facilitation and the Expert Working Group on Trade Efficiency, which led to the adoption of the 1994 Columbus Ministerial Declaration on Trade Efficiency, are more

\footnotetext{
${ }^{1}$ Such as Asia-Pacific Economic Cooperation, the Organisation for Economic Co-operation and Development, the United Nations Conference on Trade and Development, the United Nations Economic Commission for Europe, the United Nations Centre for Trade Facilitation and Electronic Business, the World Bank, and the WTO.

${ }^{2}$ Former US trade representative and former president of the World Bank.

${ }^{3}$ The Final Act of the conference recommended that UNCTAD "should promote, within the United Nations family, arrangements for: [...] (c) Intergovernmental action for research into improved marketing techniques, the organization of trade fairs, the dissemination of market intelligence and the simplification of formalities relating to customs procedures, commercial travel, etc." (UNCTAD, 1964).
} 
than two decades old. The declaration, in turn, was instrumental for the inclusion of trade facilitation in the WTO agenda at the Singapore ministerial conference in 1996. Trade facilitation became more visible once it surfaced on the radar of the WTO and began to figure prominently in the work programs of many institutions and international treaties, including various regional trade agreements.

The success of the Bali ministerial conference was acknowledged by political leaders all over the world and its coverage in the electronic and print media was also overwhelmingly trade facilitation-centric. After protracted negotiations spread over more than a decade, the conclusion of negotiations on trade facilitation paved the way for the first new agreement since the creation of the WTO in 1995. The Bali outcome is the 'agreed text' pending legal review/scrubbing; it will become part of WTO law after acceptance of the Protocol of Amendment by two thirds of the WTO members and enter into force thereafter.

The TFA will create legally enforceable binding commitments across 160 WTO members, including Pakistan, to expedite the movement, release, and clearance of goods (including goods in transit) and will improve cooperation among WTO members on customs matters. The TFA will also provide for "special and differential treatment," such as the staging of implementation after entry into force for developing and leastdeveloped country (LDC) members in accordance with their respective implementation capacities. Developed countries and development partners will provide developing countries with financial and technical assistance to ensure that all WTO members ultimately implement all the provisions of the TFA.

\section{The Contours of the TFA}

The WTO-developed definition of trade facilitation, after it was tasked for exploratory work, is "the simplification and harmonization of international trade procedures" with trade procedures being "the activities, practices and formalities involved in collecting, presenting, communications and processing data required for the movement of goods" in international trade (WTO, 1998). When the WTO Doha Development Agenda was adopted in 2001, the Doha Ministerial Declaration provided that the Council for Trade in Goods "shall review and as appropriate clarify and improve relevant aspects of Articles V, VII and X of the GATT 1994 and identify the trade facilitation needs and priorities of members, in 
particular developing and least-developed countries" (cited in International Trade Centre, 2013, p. 4).

In July 2004, WTO members agreed to start negotiations on trade facilitation under the mandate set out in Annex D of the July package. They agreed that the negotiations "shall aim to clarify and improve relevant aspects of Articles V, VIII and X of the GATT 1994 with a view to further expediting the movement, release and clearance of goods, including goods in transit."4

When an agreement was finally reached at the Bali ministerial conference in December 2013, WTO members had achieved a consensus text. Besides the preamble and final provisions, the TFA has two sections: Section I covers the substantive provisions ${ }^{5}$ in 13 articles (briefly discussed below) and Section II deals with the Special and Differential Treatment provisions for implementing the TFA by developing country and LDC members.

Articles 1 to 5 of the TFA, which clarify and improve on Article X of GATT 1994, are a crucial step in eventually materializing transparencyone of the three main principles of the WTO-together with nondiscrimination and most-favored-nation treatment. The TFA will require all WTO members to publish timely, accurate, and easily accessible information on trade laws, applicable fees and tariffs, procedures to appeal customs decisions, and penalties. This is essential for the transparency, predictability, and efficiency of international commercial transactions. The online availability of information and 'enquiry points' will provide timely and relevant information.

Consultations with stakeholders for formulating trade policy and procedures will give the trade community an opportunity to address potential challenges and become familiar with new practices before they take effect. The TFA also requires advance notice of new procedures before they are implemented and obligates members to issue binding rulings for tariff classification and the origin of goods to enhance the certainty and predictability of trade. Similarly, the system of administrative and judicial appeals will enhance the transparent application of laws and regulations.

Articles 6-10 of the TFA primarily cover the fees and charges for import, export, and transit, expanding on Article VIII of GATT 1994. The

\footnotetext{
${ }^{4}$ http://www.wto.org/english/tratop_e/tradfa_e/tradfa_negoti_e.htm

${ }^{5}$ In the context of the TFA, besides "articles," the terms "provision(s)" and "measures(s)" have been used interchangeably without any distinction.
} 
mandatory provisions focusing on customs procedures, fees and charges, and documentation, should lead to a shift from physical controls at border crossings (which often entail delays and interference in the movement of goods) to information treatment, resulting in higher security and easier flows of commerce. Alongside pre-arrival processing, these provisions also promote risk-based processing, post-clearance audit, and additional trade facilitation measures for more compliant traders. These customs rules incorporate some of the best customs practices recommended by the WCO, which countries with the most advanced administrative reforms adopted and implemented some time ago.

Similarly, WTO members will be required to establish procedures for expedited shipment to facilitate the access of traders-including small and medium enterprises (SMEs) - to ensure just-in-time delivery. Members will be obligated to review and reduce the formalities and documents required for international trade and apply these uniformly throughout the country. Moreover, they will have to ensure coordination between all border regulatory agencies at the national level and to the extent possible with those of neighboring members. Establishing a single window for all trade procedures will promote coordination. Such cooperation will reduce compliance and enforcement costs and promote efficiency gains.

Article 11 on freedom of transit seeks to improve security and safety while simultaneously facilitating the efficient movement of goods in transit. The article repeats the provision in GATT 1994 (Article V) that each member state is to treat products in transit no less favorably than if they were being transported to their destination without going through the territory of that member state. Formalities, documentation requirements, and customs controls on traffic in transit are to be limited in scope and applied only at the beginning and conclusion of the transit operation. Other facilitations, such as advance filings and discharging guarantees as provided for import and export, are also included. Procedures governing traffic in transit are especially important for international trade with landlocked countries.

A number of other issues not found in GATT 1994 are included in Articles $12-13$ of the TFA. These include customs cooperation and institutional arrangements such as national trade facilitation committees.

Article 12 on customs cooperation sets out the terms and requirements for improving customs cooperation. The broad aim is to establish a framework for cooperation that obligates WTO members to 
share information in order to ensure the orderly coordination of customs control while respecting the confidentiality of the information held. The article sets out the procedures that members must follow when a customs authority needs information from its counterpart in another member country to verify an import or export declaration because of suspicions over the truth or accuracy of the declaration.

Such information must be requested in writing, and the authority to which the request is made must promptly supply the information requested to the extent and in the form it is available. Information received must be held in strict confidence by the requesting authority and not disclosed without specific written permission from the supplying member. There are also provisions for the postponement or refusal of a request, including for reasons of lack of reciprocity in meeting a similar request in the opposite direction. The article also makes clear that members may enter into or maintain bilateral, plurilateral, or regional agreements for sharing or exchanging customs information and data.

Through institutional arrangements in Article 13 of the TFA, the WTO Committee on Trade Facilitation has been established to oversee the operation of the agreement and further its objectives. Member states have agreed that the operation of the agreement should be initially reviewed four years after it has entered into force and periodically thereafter. The committee will provide a permanent forum for members to discuss issues related to the implementation of the TFA and for discussions among members to find mutually satisfactory solutions promptly.

The importance of coordination with all domestic stakeholders is also acknowledged by agreeing to a mandatory provision in the TFA to form or maintain a national committee on trade facilitation or to designate an existing mechanism for this purpose. Among the functions that such bodies may perform, the agreement stipulates that they will facilitate the domestic coordination and implementation of the TFA. Private businesses will need to learn about such obligations and engage meaningfully with their governments to establish how such coordination mechanisms can help them bring their perspective into policymaking and implementation of the TFA.

The Annex lists the title of all the articles of the TFA. These titles, however, do not confer any rights or obligations for which the text of every provision is the authentic source. 
Section II of the TFA outlines the implementation modalities for WTO members. The agreement will be binding in its entirety for all WTO members. Developed countries will implement all the provisions immediately on its entry into force. Developing country and LDC members will self-designate these provisions into different categories as given below:

- Category A commitments are those that a member has designated for implementation on entry into force of the TFA.

- Category B commitments are those that a member has designated for implementation on a date after a transitional period.

- Category C commitments are those that a member has designated for implementation on a date after a transitional period and the acquisition of implementation capacity through the provision of technical assistance and support for capacity building.

Similarly, developing country and LDC members will make their own sovereign decisions concerning the date of implementation for each provision; this includes linking the implementation of various provisions to the acquisition of implementation capacity, which development partners and bilateral donors will help provide in the form of technical and financial assistance.

For Category C commitments, each country concerned will seek from donor agencies the technical assistance and support for capacity building it requires. An 'early warning' procedure has been established to cover situations in which a country experiences difficulty in (i) obtaining the support required or (ii) implementation without technical assistance and needs to transfer certain commitments from Category B to Category C. In such cases, notification to the Committee on Trade Facilitation is envisaged. The individual commitments of all developing country and LDC members will form part of the agreement and be published.

\section{The Relevance of the TFA}

The TFA was adopted on 7 December 2013 as part of the Bali package and is a major step toward more transparent and predictable global trade transactions. While its economic impact may be quite different from what recent studies envisage in terms of "boosting the world economy by USD 1 trillion and creating 21 million jobs" (Peterson Institute for International Economics, 2013), the consequences of its implementation will need to be fully evaluated in the next five to ten years. A recent study 
by the World Economic Forum in collaboration with Bain and Company and the World Bank (2013) shows that reducing supply chain barriers to trade could increase GDP up to six times more than removing tariffs. Of course, all these benefits can only occur if and when the developing members of the WTO are in a position to implement and take advantage of the mandatory and progressive measures contained in the new agreement. The economic benefits will be proportionate to the additional benefits associated with the implementation of these measures and will also depend on the quality of implementation.

The expected reduction in transaction costs and time is most often presented as the core benefit of trade facilitation. On a case-by-case basis, the most obvious candidates among those benefiting from the provisions of the TFA are SMEs as well as the perishable and intermediate goods sectors in LDCs and landlocked developing countries. The main reason is that most large companies dealing either with bulk trade (such as grains, minerals, chemicals, or oil products) or end-consumer goods (such as electronics or apparel) have already, one way or the other, found a solution to their operational bottlenecks all over the world. Overland transit for landlocked countries or efforts to link ports/airports to SME importer or exporter premises remain areas in which trade facilitation would make all the difference for small businesses in many developing countries.

The efficiency acquired by public actors as a result of implementing the TFA will benefit the trading community in its efforts to access international markets under conditions similar to their competitors in most advanced countries. These benefits will be reflected in measurable reduced transaction costs and times and also in terms of predictability and transparency; this, in turn, will be attractive to external partners willing to join developing country counterparts in global production chains.

Trade facilitation aims not only to simplify the documentation required for clearing goods, but also the procedures employed by border agencies. Focusing on the biggest risks allows border agencies to speed up the flow of goods across the border and increases the collection of duties. Trade facilitation has been described as a classic 'win-win' subject for developing and developed countries. Nonetheless, some developing countries remain concerned about the potential costs of implementing trade facilitation commitments and have sought commitments from developed countries and other donors to assist in the implementation process. 
Global standards in trade facilitation and transport can help transfer good practices and technologies to developing countries. This contributes directly to development as it enhances e-governance, improves information technology (IT) connectivity, and streamlines processes to save time and financial costs. The administrative culture embedded in the mandatory provisions of the first ten articles of the TFA is expected to bring about a substantial transformation. In the field of publication and transparency, for example, some of the reforms to be made in many developing countries and LDCs will induce a new way of doing business.

Such reforms are often linked to IT and intelligent systems; they are likely to result in new working methods in public offices, which will need to adapt to a world of easily available information. New skills, knowledge, and mindsets will be required to implement the spirit of the TFA. Competencies in the public sector will have to evolve from control to monitoring and regulatory functions, using intelligence activities and good governance practices to ensure safety and security standards and the operation of transparent and nondistorted trade and transport markets.

Beyond the impact on trade, there is a direct link between trade facilitation and development: most specific trade facilitation reforms are positive steps toward human and institutional development. They help small traders enter the formal sector, make economic activity more transparent and accountable, promote good governance, reduce corrupt practices, generate better-quality employment, strengthen IT capabilities, and generally help modernize societies. For example, trade facilitation measures such as interagency coordination, the right of appeal, and enquiry points could form part of general national reforms not only in the context of international trade, but also within broader public sector modernization programs.

Trade facilitation reforms tend to have a high return on investment. Private traders and operators as well as the public sector save on costs and time. Moïsé and Sorescu (2013) have assessed the impact of trade facilitation measures based on 16 TFIs on trade volume and trade costs for 107 countries, including Pakistan (96 WTO members and 11 WTO observers). They find that improved TFIs reduce the cost of trade by 14.1 percent for low-income countries, 15.1 percent for middle-income countries, and 12.9 percent for upper middle-income countries. The saving generated by facilitating trade can be channeled into other productive and profitable ventures, thus initiating a virtuous circle. Many specific trade facilitation measures, such as pre-arrival processing, automation, electronic 
submission, and risk assessment, help reduce the time it takes to process trade transactions.

\section{The Status of Pakistan's TFA Implementation and International TFIs}

The TFA is clearly a customs-centric agreement that aims to reduce inefficiencies, particularly at border crossing points. Over the last two decades, Pakistan, too, has carried out a series of much needed reforms in this respect. Accordingly, the implementation level of customs-related provisions is relatively high in Pakistan. This is corroborated by UNCTAD (2013), which points out that

the level of full implementation of the individual tradefacilitation measures suggests that measures with the strongest customs-related component, covered by Articles 4 , 7, 10, 11 and 12 are characterized by high implementation rates. At the same time, most of the cross-sectoral or crossagency measures such as single window, enquiry points, publication of trade-related information, disciplines on fees and charges, together with some advanced customs techniques such as advance ruling and authorized operators, have the lowest implementation rates.

The range of initiatives in automation indicates this clearly. This paper is not intended to comment on customs automation per se, but it is worth pointing out that considerable effort has gone into reforming the customs clearance system in Pakistan over the last 25 years. In the context of the TFA, Pakistan has already invested time and resources in improving its efficiency, whether as a national initiative supported by development partners ${ }^{6}$ or as a result of ratifying the Revised Kyoto Convention of the WCO. These deserve special mention although they are far from perfect.

How Pakistan has fared so far in terms of improving processes and achieving results can be gauged from different international indicators. Before discussing these, two points are worth mentioning. First, these indicators are invariably perceptions-based and are not necessarily objective measurements of the selected area. Second, and related to the first, the absolute values may not necessarily be devoid of any incorrect indication. However, as tools for comparison with other countries or regions, they are reasonably representative performance benchmarks.

\footnotetext{
${ }^{6}$ Different initiatives with the World Bank, including the Tax Administrative Reform Program.
} 
The UNCTAD Trade and Transport Facilitation Project II (2011) has assessed Pakistan's readiness to implement the measures proposed in the TFA. The report provides an insight into the current status of trade facilitation measures in Pakistan, indicating that more than 90 percent of the proposed measures have been fully or partially implemented. If the study's findings are calibrated as per the final text of the TFA, it is heartening to note that Pakistan's compliance level is fairly high. To what extent this translates into reduced costs and time for daily transactions is another significant aspect to be explored.

Apart from this Pakistan-specific study, we take three other sources of information into account for international comparisons of trade facilitation: the World Bank's logistics performance index (LPI) for $2012^{7}$ (see Arvis et al., 2012), the World Bank's (2012) Doing Business report, and Lawrence, Hanouz, and Doherty (2012). These three studies provide detailed data at the world level, allowing comparisons with other countries including at the regional level. For purposes of comparison, we will look at four members of the South Asian Association for Regional Cooperation (SAARC) - India, Pakistan, Bangladesh, and Sri Lanka. The data below offer some insight into the nature of the trade facilitation issues presently faced by Pakistani traders.

The LPI is constructed from six indicators using principal component analysis - a standard statistical technique used to reduce the dimensionality of a dataset. The World Bank has, so far, produced three editions of the LPI, 8 the first having been published in 2007. Pakistan ranks 71 in the third edition (Arvis et al., 2012) with a score of 2.83 (on a scale of 1 to 5) and its performance is equivalent to 58.4 percent of the highest performer, i.e., Singapore (100 percent) as compared to India at 46 with a score of 3.08 and 66.4 percent (Table 1). Other SAARC members rank lower than Pakistan. While its own rank and score is not a comfortable one, two aspects are encouraging. At 71 in 2012, Pakistan's rank has improved significantly from 110 in 2010. Pakistan is also among the top ten performers in the group of lower middle-income countries in 2012.

\footnotetext{
${ }^{7}$ The rankings are available at http://lpisurvey.worldbank.org/international/global.

${ }^{8}$ The LPI measures on-the-ground trade logistics performance in 155 countries (2012 edition) to understand the challenges they and their trading partners face in reducing logistical barriers to international commerce. The international score for the LPI uses six dimensions, of which we have selected three (relating to customs and trade procedures) for comparison: (i) the efficiency of the clearance process (i.e., speed, simplicity, and predictability of formalities) by border control agencies, including customs (first pillar); (ii) the ease of arranging competitively priced shipments (third pillar); and (iii) timeliness of shipments in reaching their destination within the scheduled or expected delivery time (sixth pillar).
} 
Table 1: LPI ranks and scores for selected countries

\begin{tabular}{|c|c|c|c|c|c|c|c|c|}
\hline \multirow[b]{2}{*}{ Country } & \multicolumn{2}{|c|}{ LPI } & \multicolumn{2}{|c|}{ Customs } & \multicolumn{2}{|c|}{$\begin{array}{l}\text { International } \\
\text { shipments }\end{array}$} & \multicolumn{2}{|c|}{ Timeliness } \\
\hline & Rank & Score & Rank & Score & Rank & Score & Rank & Score \\
\hline India & 46 & 3.08 & 52 & 2.77 & 54 & 2.98 & 44 & 3.58 \\
\hline Pakistan & 71 & 2.83 & 46 & 2.85 & 67 & 2.86 & 82 & 3.14 \\
\hline Sri Lanka & 81 & 2.75 & 72 & 2.58 & 51 & 3.00 & 108 & 2.90 \\
\hline $\begin{array}{l}\text { Bangladesh } \\
\text { (2010) }\end{array}$ & 79 & 2.74 & 89 & 2.33 & 61 & 2.99 & 69 & 3.46 \\
\hline
\end{tabular}

Source: Arvis et al. (2012).

Pakistan has faired particularly well on the first indicator, i.e., efficiency of customs and border management clearance (rank $=46$ ) where it is ahead of India (rank = 52) and the other SAARC countries. However, it lags behind on the sixth indicator, the frequency with which shipments reach consignees within the scheduled or expected delivery time $($ rank $=82)$.

The second set of international indicators is from the World Bank's (2012) Doing Business report. ${ }^{9}$ Table 2 gives Pakistan's position relative to South Asia and the OECD countries. Table 3 shows that Pakistan is ranked second after Sri Lanka in the general doing-business average.

\footnotetext{
${ }^{9}$ This is based on different pillars, but we look at the pillar 'trading across borders,' which takes into account six indicators: (i) documents to export (number); (ii) the time needed to comply with all procedures required to export goods (if a procedure can be accelerated at additional cost, the fastest legal procedure is chosen); (iii) the cost associated with all procedures required to export goods (includes the cost of documents, administrative fees for customs clearance and technical control, customs broker fees, terminal handling charges, and inland transport); (iv) the total number of documents required per shipment to import goods (documents required for clearance by government ministries, customs authorities, port and container terminal authorities, health and technical control agencies, and banks); (v) the time needed to comply with all procedures required to import goods (if a procedure can be accelerated at additional cost, the fastest legal procedure is chosen); and (vi) the cost associated with all procedures required to import goods (includes the cost of documents, administrative fees for customs clearance and technical control, customs broker fees, terminal handling charges, and inland transport).
} 
Table 2: Doing-business indicators

\begin{tabular}{lccr}
\hline Country/region/indicator & Pakistan & South Asia & OECD \\
\hline Documents to export (number) & 8 & 8 & 4 \\
Time taken to export (days) & 21 & 33 & 11 \\
Cost of exporting (USD per container) & 660 & 1,787 & 1,070 \\
Documents to import (number) & 8 & 10 & 4 \\
Time taken to import (days) & 18 & 34 & 10 \\
Cost of importing (USD per & 725 & 1,968 & 1,090 \\
container) & & & \\
\hline
\end{tabular}

Source: World Bank (2012).

Table 3: Ease of doing business, South Asia

\begin{tabular}{lc}
\hline Country & Ease of doing business (rank) \\
\hline Sri Lanka & 85 \\
Pakistan & 110 \\
Bangladesh & 130 \\
India & 134 \\
\hline
\end{tabular}

Source: World Bank (2012).

The most recent Trading Across Borders data from the World Bank (2014) highlights some concern that Pakistan may be sliding back on its trade facilitation efforts. The country's ranking for both export time and costs has slipped, as has its overall position compared to other regional partners, including the Economic Cooperation Organization. At this time more than any other, it is crucial for Pakistan to maintain its progress and continue to focus on a forward-looking strategy.

The third source of TFIs is the Global Enabling Trade Report (GETR) study by Lawrence et al. (2012), ${ }^{10}$ which provides detailed data for 142 countries, four of which are members of the South Asian Free Trade Area (SAFTA) - India, Pakistan, Bangladesh, and Sri Lanka. These data offer some insight into the nature of trade facilitation issues currently

\footnotetext{
${ }^{10}$ Four of this year's nine indicators from the GETR study are directly relevant to trade facilitation and have been selected to give a general idea of the scope of challenges that Pakistan faces and as an indication of its current status. The GETR survey asked respondents to assess the efficiency of the selected indicators on a scale of 1 to 7 , with 1 being slow and inefficient and 7 being among the world's most efficient. Overall, respondents found that ineffective government bureaucracy, an inadequate infrastructure, and corruption were among the most problematic factors in doing business in Pakistan.
} 
facing Pakistani traders and allow, to some extent, comparison with other countries in the region. Table 4 shows that Pakistan lags behind the selected SAFTA countries overall as well as on other indicators, except for border administration, efficiency of customs procedures, and efficiency of import/export procedures. This indicative assessment could help design trade policies that focus on those indicators that need the most improvement. The GETR data give not only a sense of the range of conditions among SAFTA countries, but also how these countries compare with the rest of the world (see Lawrence et al., 2012).

Table 4: GETR indicators for selected countries

\begin{tabular}{lrrrrrrrrrr}
\hline & $\begin{array}{l}\text { Enabling } \\
\text { business } \\
\text { environment }\end{array}$ & \multicolumn{2}{c}{$\begin{array}{c}\text { Border } \\
\text { administration }\end{array}$} & $\begin{array}{c}\text { Efficiency of } \\
\text { customs } \\
\text { administration }\end{array}$ & $\begin{array}{c}\text { Efficiency of } \\
\text { import/export } \\
\text { procedures }\end{array}$ & $\begin{array}{c}\text { Transparency } \\
\text { of border } \\
\text { administration }\end{array}$ \\
\cline { 2 - 12 } Country & Rank & Score & Rank & Score & Rank & Score & Rank & Score & Rank & Score \\
\hline Sri Lanka & 73 & 3.95 & 73 & 3.89 & 85 & 3.76 & 47 & 5.02 & 92 & 2.89 \\
India & 100 & 3.55 & 77 & 3.82 & 70 & 4.10 & 79 & 4.38 & 84 & 2.99 \\
Bangladesh & 109 & 3.46 & 100 & 3.33 & 103 & 3.26 & 86 & 4.22 & 115 & 2.52 \\
Pakistan & 116 & 3.39 & 71 & 3.92 & 66 & 4.20 & 56 & 4.86 & 101 & 2.69 \\
\hline
\end{tabular}

Source: Lawrence et al. (2012).

The variance in these data and Pakistan's performance suggest that these indicators might not present conclusive results, but they can certainly be used to make an informed guess concerning the country's performance relative to other players in the region and the world. This, in turn, could help design trade policy interventions in a focused and calibrated manner.

\section{Implications for Trade Policy}

All 160 WTO members have a binding obligation to implement all 37 measures included in the 13 articles of the TFA on its entry into force. However, developing country and LDC members have the option of tailoring their implementation period to the country's capacity to implement such measures. For Category $C$ measures, these members will also be entitled to seek technical and financial assistance and link the implementation to the acquisition of implementation capacities. Put simply, the starting line for different members may be different, but the finish line will be the same, with some members reaching it later and with some support. Decisions concerning the categorization and timing of implementation will be sovereign decisions, which every developing country and LDC member, including Pakistan, will make as it sees fit. 
Trade policy formulation in Pakistan is not very different from policymaking in other sectors such as health, labor, or tourism, or from initiatives taken in other economies at a similar level of development. It is usually a periodic exercise with very little implementation monitoring. Decisions that require legal changes are usually implemented quicker, but their effectiveness is seldom evaluated. Other initiatives pursuing particular objectives are invariably implemented as routine matters and are rarely monitored or evaluated in a systematic way.

Generally, policymaking in Pakistan is driven by an ad hoc bureaucratic mindset combined with some degree of lobbying by interested business groups; trade policy is no exception. However, where international commitments are concerned, policy interventions are more likely to be timely and in line with international obligations. ${ }^{11}$ An example is the amendments made to Pakistan's customs tariff every four years in line with its obligations under the Harmonized Commodity Description and Coding System (HS Convention).

The TFA's first impact on trade policy will be to overcome the inertia of business-as-usual among trade policymakers. The Bali ministerial decision requires all WTO members to submit their Category A commitments by July 2014. Similarly, on entry into force (expected by August 2015), the Government of Pakistan will be required to notify the measures it has designated under Categories B and C, along with indicative dates of implementation.

Trade policymakers in Pakistan do not, therefore, have the luxury of time. To fulfill its obligations, Pakistan must analyze all 37 provisions and select those it intends to notify as Category A commitments (those measures that are in place or will be implemented immediately once the TFA enters into force). Pakistan will not be starting from scratch: many of the measures specifically relating to customs are already part of its existing legislation and being implemented. Even before it comes into force, the TFA will have a positive impact on governments working to review the international agreement vis-à-vis domestic legislation and the categorization of different measures.

It is worth pointing out that the approach of different governments to implementing the TFA will vary according to the

\footnotetext{
${ }^{11}$ However, the implementation of the WTO Agreement on Customs Valuation and Trade-Related Investment Measures in Pakistan suggests that certain international obligations are 'disregarded' or 'circumvented' on one pretext or another.
} 
intended outcome. Governments may aim only to achieve compliance with their international obligations, which is a relatively easy way out. The other option would be to design an implementation plan for the measures included in the TFA so as to achieve a higher degree of trade facilitation. This is a more ambitious outcome where, instead of merely achieving legal compliance with procedures, the benchmarks could be result-oriented to reduce clearance times, etc.

The scope of the TFA extends beyond the trade policy wing of the government as the measures contained therein relate to all border regulatory agencies. In Pakistan, the Ministry of Commerce is responsible for trade policy formulation, but in the case of the TFA, it may only be able to decide on the categorization of measures in consultation with other government ministries, especially the Federal Board of Revenue, which is responsible for customs measures. This will require the ministry to open channels of communication with other border regulatory agencies. The structure of international obligations will thus initiate inter-ministerial consultation and coordination that will apply not only during the categorization process, but also to the subsequent implementation of certain measures.

This has serious implications for the so-called 'turf war' between different government agencies that are apt to be possessive about their areas of work as distributed in the 'Rules of Business.' In the case of the TFA, the responsibility for implementation will lie with the Ministry of Commerce, but the federal government will only be in a position to achieve compliance with its international obligations if its different wings communicate and collaborate with each other on a sustainable basis.

The TFA and technical assistance sought from development partners will also affect the way in which the government (in particular, the Economic Affairs Division) enters into contracts with donors for international assistance. In the case of the TFA, funds will be tied to particular provision(s) of the agreement. The demand-driven, provisionspecific proposal will also include an agreement concerning the mechanism for ascertaining the acquisition of capacity to implement that particular provision as well as the indicative date by which that provision is to be implemented. Again, this will require coordination with the relevant implementation agency and regular monitoring for the seamless delivery of the agreed outcomes. 
The TFA also obligates WTO members to have in place a national committee on trade facilitation to facilitate domestic coordination and the implementation of various provisions. The TFA is silent on the composition of such committees, but going by international best practices, members should be drawn from all the border regulatory agencies as well as from the private sector. Pakistan has already established the National Trade and Transport Facilitation Committee with a membership of around 40 ministries and private sector bodies. This is a vibrant forum for the coordination of trade policy formulation. Trade policymakers will be obligated to make the committee financially viable and institutionalize its working such that it becomes a forum for domestic coordination compliant with TFA obligations.

Similarly, the TFA will obligate the government to coordinate with its neighboring countries' border regulatory agencies. This three-way coordination-with the private sector, with other border regulatory agencies, and with neighbors' cross-border regulatory agencies, preceded by consultation with the private sector-is bound to improve efficiency, transparency, and buy-in from the stakeholders involved. It will also result in improved implementation for the government and businesses, and influence the 'attitude' of public sector agencies from regulators to facilitators. The TFA aims to promote interaction between the private and public sectors, where both treat each other as 'business partners' working for the good of the country.

Once meaningful benchmarks have been established, measuring success by results (i.e., lower transaction costs) rather than inputs (i.e., procedural changes) is far more likely to yield economic benefits for Pakistan. For this approach to succeed, however, the private sector must be involved in identifying where changes are needed and in monitoring progress.

The involvement of private sector stakeholders in the national policymaking process is not without challenges. Most public sector officials perceive the private sector as being either unfamiliar with the subject matter or unwilling to give quality time. Those who come forward for consultation may expect their particular views to shape the policy outcome. This does not mean, however, that they should not be consulted. Policymakers must plan to build the capacity of the private sector (possibly with the help of development partners) so that it can offer useful input, at least in identifying the gaps that need to be bridged. 
Another important aspect of consultation with the private sector is deciphering the common denominator. Invariably, the input from different sectors will represent their personal opinions and not necessarily a 'representative' voice. In many cases, such input and proposed solutions vary among different business sectors and are presented to further their own business agendas, sometimes at the cost of other sectors. Policymakers must design the consultation process in a manner that institutionalizes the process and can overcome such situations.

Trade facilitation is a dynamic, ongoing effort. Policymakers should keep in mind that trade facilitation, unlike tariff reduction, is open-ended. Once tariff rates have been reduced to zero, the tariff reduction exercise is complete. In contrast, steps can always be taken to further reduce the cost of cross-border transactions, which (in addition to unforeseen procedural impediments to maintaining an open trade regime) need to be addressed continually to remain abreast of the dynamic trading realities of global connectivity.

Finally, it is relatively simple to agree on an ambitious trade facilitation agenda; the challenge will lie in creating an enabling environment that gives the agenda effect. Policymakers should recognize that the standard bureaucratic control/enforcement approach is unlikely to be effective for many trade facilitation measures. This is because trade facilitation covers numerous procedures that take place along multiple steps of the international supply chain-both at the border as well as behind. Unlike tariff rate reductions, which are typically administered by a single government agency, trade facilitation measures require many different departments and agencies to cooperate and comply with one another, including with those of bordering countries or trading partners.

\section{Conclusion}

While every trader and government agency may wish to improve the competitiveness of its sector, this is not necessarily matched by its actions. The gap is usually attributed either to lack of resources or expertise. The Bali TFA qualitatively offers avenues to fill these gaps and specifies which areas would help reduce the inefficiencies of international trade. It not only offers countries the flexibility to tailor reforms in accordance with the prevailing development level, but also presents modalities for soliciting support from development partners, bilateral and international, to address issues of expertise and resources through technical assistance and support for capacity building. 
Trade facilitation has two peculiar characteristics. It is a multiagency function where consultation, coordination, and collaboration are key to achieving any meaningful success. It is also an ongoing process. No country may ever be in a position to say that its reforms are complete (as one might easily claim once the tariff rate is zero). The focus of any policy must be designed and implemented keeping in view both these aspects.

Pakistan's performance in the area of trade facilitation has been relatively good, especially in customs, but there is clearly ample room for improvement. While many customs-centric measures are in place (if achieving legal compliance is the performance threshold), the challenge will be to improve these measures and reduce any remaining inefficiencies in order to save time and costs. The TFA provides an opportunity to reexamine the laws and procedures in place as well as their implementation and to address these in a manner that is efficient and predictable. Monitoring key initiatives is equally important.

The TFA also requires that the business sector be consulted and involved in policymaking as well as in developing the relevant national legislation. Some ad hoc initiatives have been introduced, but primarily to accommodate influential lobby groups or to send the message that government functionaries are open to consulting this sector. The challenge will be to persuade public functionaries that private sector stakeholders are the equivalent of their business partners in this undertaking.

Policymakers must also heed wider public opinion, especially if it is represented by a 'single voice.' It may not be binding on the government to accept every view put forward by private sector stakeholders, but the former is obligated to consider the problems or solutions presented. Along the way, it is also incumbent on policymakers to build the capacity of the private sector, enabling it to become an effective partner in national policymaking and implementation. 


\section{References}

Arvis, J.-F., Saslavsky, D., Ojala, L., Shepherd, B., Busch, C., \& Raj, A. (2014). Connecting to compete: Trade logistics in the global economy. Washington, DC: The World Bank.

International Trade Centre. (2013). WTO Trade Facilitation Agreement: A business guide for developing countries. Geneva: Author.

Lawrence, R. Z., Hanouz, M. D., \& Doherty, S. (Eds.). (2012). The global enabling trade report 2012: Reducing supply chain barriers. Geneva: World Economic Forum.

Moïsé, E., \& Sorescu, S. (2013). Trade facilitation indicators: The potential impact of trade facilitation on developing countries' trade (Trade Policy Paper No. 144). Paris: OECD Publishing.

Peterson Institute for International Economics. (2013). Payoff from the World Trade Agenda 2013. Washington, DC: Author.

United Nations Conference on Trade and Development. (1964). Proceedings of the United Nations Conference on Trade and Development, Geneva, 23 March-16 June. New York, NY: United Nations.

United Nations Conference on Trade and Development. (2013). Review of maritime transport 2013. Geneva: Author.

United Nations Conference on Trade and Development, Trade and Transport Facilitation Project II. (2011). Study of trade facilitation initiatives for achieving compliance with the future WTO Trade Facilitation Agreement. Islamabad: Author.

World Bank. (2012). Doing business 2012: Doing business in a more transparent world. Washington, DC: Author.

World Bank. (2014). Trading across borders in Pakistan | Doing business [Webpage]. Retrieved from http://www.doingbusiness.org/data/ exploreeconomies/pakistan/trading-across-borders/

World Economic Forum, Bain and Company, and the World Bank. (2013). Enabling trade: Valuing growth opportunities. Geneva: World Economic Forum.

World Trade Organization. (1998). WTO Trade Facilitation Symposium, 910 March 1998: Report by the Secretariat. Geneva: Author. 
Annex

Article 1: Publication and availability of information

1. Publication

2. Information available through the Internet

3. Enquiry points

4. Notification

Article 2: Opportunity to comment, information before entry into force and consultation

1. Opportunity to comment and information before entry into force

2. Consultations

Article 3: Advance rulings

Article 4: Appeal or review procedures: Right to appeal or review

Article 5: Other measures to enhance impartiality, nondiscrimination and transparency

1. Notifications for enhanced controls or inspections

2. Detention

3. Test procedures

Article 6: Disciplines on fees and charges imposed on or in connection with importation and exportation

1. General disciplines on fees and charges imposed on or in connection with importation and exportation

2. Specific disciplines on fees and charges imposed on or in connection with importation and exportation

3. Penalty disciplines

Article 7: Release and clearance of goods

1. Pre-arrival processing

2. Electronic payment 
3. Separation of release from final determination of customs duties, taxes, fees and charges

4. Risk management

5. Post-clearance audit

6. Establishment and publication of average release times

7. Trade facilitation measures for authorized operators

8. Expedited shipments

9. Perishable goods

Article 8: Border agency cooperation

Article 9: Movement of goods under customs control intended for import

Article 10: Formalities connected with importation and exportation and transit

1. Formalities and documentation requirements

2. Acceptance of copies

3. Use of international standards

4. Single window

5. Pre-shipment inspection

6. Use of customs brokers

7. Common border procedures and uniform documentation requirements

8. Rejected goods

9. Temporary admission of goods/inward and outward processing

Article 11: Freedom of transit

Article 12: Customs cooperation

Article 13: Institutional arrangements

1. Trade facilitation committee

2. National committee on trade facilitation 